\title{
SELECTIVE ADVANTAGE OF THE CYTOPLASMIC RESPIR- ATORY MUTANT OF SACCHAROMYCES CEREVISIIE IN A COBALT MEDIUM.
}

\author{
PEARL HORN* and D. WILKIE \\ Department of Botany, University College London
}

Received 28.ii.66.

\section{INTRODUCTION}

IT has become apparent from the study of respiratory-deficient mutants of Saccharomyces cerevisie that there is an extra-chromosomal genetic unit (the rho particle) necessary for respiratory competence in this organism (see Wilkie, 1964). Such mutants are termed "vegetative petites" or simply rho- (Chen et al., 1950).

As much of the evidence for the existence of the rho particle is based on genetical studies which provide negative evidence, induction experiments have been looked at as a means of detecting other properties of this unit. For example the ability of acriflavine (Ephrussi et al., 1949) and UV light (Raut and Simpson, I955; Wilkie, 1963) to induce rho- cells has indicated that the cytoplasmic factor is a nucleic acid.

One of the original aims of the present work was to test the inducing ability of certain chemical compounds. The first to be tested was cobalt sulphate for the reason that cobalt salts were shown by Hirota (1956) to cause "F-elimination" in F+ cells of $E$. coli. The fact that acriflavine is an agent of petite induction and F-elimination (Hirota, I 960 ) has suggested that the rho determinant in yeast and the bacterial episome may have common features.

\section{MATERIALS AND METHODS}

Cultures were grown on YEP broth ( 1 per cent. Difco yeast extract, 2 per cent. Oxoid peptone) with glucose ( 2 per cent.) as fermentable substrate, or glycerol (4 per cent. $w / v$ ) as non-fermentable substrate. Solid medium contained $\mathrm{r} \cdot 5$ per cent. Difco agar.

For cobalt-containing medium, cobalt sulphate was added to YEP-glucose medium. The $p \mathrm{H}$ of the medium was not altered by addition of the salt.

Two strains derived from stock cultures of this laboratory were used:

strain 45RC: with markers $u r, h i, a$ (uracil and histidine requirement, $a$ mating type) and

strain r88RC: prototrophic, $\alpha$ mating type.

Respiratory deficient mutants of spontaneous origin (SP) were isolated on YEPglucose plates and induced RD mutants (AC) on YEP-glucose plates containing $20 \mathrm{ppm}$ acriflavine (supplied by Hopkins and Williams Ltd., England).

To estimate the frequency of RD cells in a population the TTC-overlay method of Ogur et al. (1957) was used as follows: cells were sampled and plated on YEP-glucose. U.S.A.

* Present address: Microbiology Dept., New York University Medical School, N.Y., 
After 5 days incubation at $30^{\circ} \mathrm{C}$. to allow for colony development, the plates were overlaid with molten agar containing $0 \cdot$ I per cent. TTC (2,3,5-triphenyltetrazolium chloride). Within a few hours $\mathrm{RC}$ colonies stain red while $\mathrm{RD}$ colonies remain white. Only those colonies which were entirely white were scored as RD.

In the strains used here it was possible to score petite colonies on a YEP medium with a high degree of certainty on the basis of their visual characteristics. RD colonies are small, white and translucent whereas normal colonies are creamcoloured and opaque. This difference was found to apply only to cytoplasmic petites $\left(r h o^{-}\right)$: gene-petites which are $r \mathrm{r}^{+}$(see Ephrussi, I953 and account of strain $\mathrm{K}_{2}$ below) look like the normal except for the general difference in size.

UV-induction experiments were carried out using a Philips 6 watt T.U.V. discharge tube with 95 per cent. of its output at wavelength $2537 \mathrm{~A}$.

To obtain anærobic cultures, plates were incubated in a BTL anærobic jar which was evacuated and filled with nitrogen. As a control, a YEP-glycerol plate inoculated with RC cells was included in the jar; no growth on this plate indicated that anærobic conditions had been achieved.

\section{COBALT SULPHATE STUDIES}

\section{(i) A respiratory-competent strain}

Lindegren et al. (1958) have reported that there was an increase in the relative proportion of RD cells in a population of $S$. cerevisia which is grown in medium containing cobalt salts. These were population studies in which cells of the respiratory-competent $(\mathrm{RC})$ strain were inoculated into nutrient broth containing various concentrations of the cobalt ion. After these cells grew for a number of generations, they were harvested and plated on cobalt-free medium. The entire population of cells grown at just sub-lethal concentrations was found to be $\mathrm{RD}$ which led the authors to conclude that the cobalt ion is an inducing agent.

In the present study, the same effect was found, i.e. cells inoculated directly into sub-lethal concentrations of cobalt sulphate $(2 \mathrm{mM})$ gave rise to a population which was almost entirely $\mathrm{RD}$.

However, if instead, the original inoculum was first grown to stationary phase in $0.5 \mathrm{mM}$ cobalt sulphate medium, and cells of this culture sequentially transferred and grown in increasing levels of cobalt sulphate ( $\mathrm{I}, \mathrm{I} \cdot 5 \mathrm{mM}$ ) and then grown in $2 \mathrm{mM}$ medium, the relative frequency of RD cells was only 5-20 per cent. of the population.

These observations became more meaningful when the cobalt tolerance of this strain, that is the maximal concentration on which non-adapted cells can grow, was determined.

\section{(ii) Cobalt tolerance of strain $45 R C$}

Strain $45 \mathrm{RC}$ was grown to stationary phase in shaking culture on non-fermentable substrate. The relative frequency of RD cells following growth on this medium is minimal, for although this variant may arise on non-fermentable medium, it cannot proliferate. When plated on glucose-YEP (a fermentable medium), I in 1225 cells from this culture gave rise to an RD colony.

Inoculi from this same culture were plated on glucose-YEP medium 
containing cobalt sulphate in a range of concentrations from $0.5-3 \mathrm{mM}$ Colonies were scored when they reached a diameter of $\mathrm{I} \mathrm{mm}$. In general, cobalt sulphate was inhibitory as evidenced by a lag in growth rate and a decrease in the number of cells which produced colonies

TABLE I

Cobalt tolerance of strain 45

\begin{tabular}{|l|c|c|c|c|}
\hline $\begin{array}{c}\mathrm{CoSO}_{4} \\
(\mathrm{mM})^{4}\end{array}$ & $\begin{array}{c}\text { Estimated No. } \\
\text { cells plated* }\end{array}$ & $\begin{array}{c}\text { No. } \\
\text { colonies }\end{array}$ & $\begin{array}{c}\text { Days to } \\
\text { develop }\end{array}$ & $\begin{array}{c}\text { Viability } \\
\text { (per cent.) }\end{array}$ \\
\hline 0.5 & 450 & 457 & 2 & 100 \\
1 & 450 & 225 & $2-6$ & 50 \\
$1 \cdot 25$ & 390 & 227 & $2-7$ & 55 \\
$1 \cdot 5$ & 450 & 3 & $0 \cdot 7$ \\
2 & $58 \times 10^{3}$ & 42 & $2-3$ & $0 \cdot 072$ \\
$2 \cdot 5$ & $58 \times 10^{4}$ & 5 & 5 & $0 \cdot 0086$ \\
3 & $58 \times 10^{5}$ & 0 & $\cdots$ & $\cdots$ \\
\hline
\end{tabular}

* Based on the cobalt-free control plates.

with increasing concentrations (table 1 ). On the cobalt-free plates I $\mathrm{mm}$. colonies developed at 2 days.

The respiratory capacity of the cells of the more tolerant colonies that arose on ${ }^{1} \cdot 5,2$, and $2.5 \mathrm{mM}$ plates was tested (table 2 ). Differential

TABLE 2

Respiratory capacities of cobalt-grown colonies (see Table I)

\begin{tabular}{|c|c|c|c|c|c|}
\hline \multirow{2}{*}{$\begin{array}{c}\text { Cobalt } \\
\text { tolerance }(\mathrm{mM})\end{array}$} & $\begin{array}{c}\text { Total colonies } \\
\text { analysed }\end{array}$ & \multicolumn{5}{|c|}{ Colony types } \\
\cline { 3 - 6 } & & RC & RD & Mixed & Non-viable* \\
\hline & 3 & 1 & 1 & 1 & $\ldots$ \\
2 & 42 & 0 & 34 & 0 & 8 \\
2 & 5 & 0 & 2 & 0 & 3 \\
\hline
\end{tabular}

* The cells of certain colonies failed to grow on either glucose or glycerol plates and are considered non-viable. A further account of loss of viability is given in subsequent sections.

growth tests (fig. I) showed that the tolerant colonies were of three types as regards the respiratory capacity of their constituent cells:

$\mathrm{I}-\mathrm{RC}$, dense growth on glucose and on glycerol;

$2-\mathrm{RD}$, dense growth on glucose, no growth on glycerol;

3- "Mixed", dense growth on glucose, but sparse growth on glycerol, that is, only some cells are RG.

(Strictly speaking, " RC" colonies are "mixed", however in the present context "mixed" is used to describe those colonies which contain less than i per cent. RC cells.)

That the RD cells of colony types 2 and 3 are vegetative petites was 
shown when they produced RD diploids when crossed to an acriflavineinduced petite.

The finding that the frequency of cells tolerant to $2 \mathrm{mM}$ is of the same order as the frequency of spontaneous petites on control plates, and that those viable colonies sampled from $2 \mathrm{mM}$ plates consist entirely of RD cells suggested that selection of pre-existing mutants is occurring at this concentration of cobalt sulphate. To explore this possibility a reconstruction experiment was performed.

Independent $\mathrm{RD}$ strains derived from strain $45 \mathrm{RG}$, one which arose on a control YEP plate and therefore of spontaneous origin (strain $45 \mathrm{SP}$ ) and one produced by acriflavine treatment $(45 \mathrm{AC}$ ), were plated on cobalt medium. Also tested was a clone of RD cells

TABLE 3

Cobalt tolerance of $R D$ strains derived from strain $45 R C$

\begin{tabular}{|c|c|c|c|c|}
\hline \multirow{2}{*}{$\underset{(\mathrm{mM})}{\mathrm{CoSO}_{4}}$} & \multicolumn{3}{|c|}{ Viability (per cent.) } & \multirow{2}{*}{$\begin{array}{l}\text { Days to } \\
\text { develop }\end{array}$} \\
\hline & ${ }_{45} \mathrm{SP}$ & $45 \mathrm{AC}$ & 4500 & \\
\hline $\begin{array}{l}0.5 \\
I \\
1 \cdot 5 \\
2 \\
2 \cdot 5 \\
3 \\
3 \cdot 5\end{array}$ & $\begin{array}{c}100 \\
100 \\
100 \\
80 \\
8 \\
\text { o.5 } \\
0\end{array}$ & $\begin{array}{r}100 \\
100 \\
100 \\
100 \\
20 \\
1 \\
0\end{array}$ & $\begin{array}{r}100 \\
100 \\
100 \\
100 \\
50 \\
5 \\
0\end{array}$ & $\begin{array}{c}2 \\
2 \\
2 \\
2 \\
5-6 \\
6 \\
\ldots\end{array}$ \\
\hline
\end{tabular}

(4500) which was isolated from a $2 \mathrm{mM}$ plate of the previous experiment. All 3 strains were grown on cobalt-free medium prior to plating. The results (table 3 ) clearly show that $\mathrm{RD}$ cells, regardless of origin are more tolerant to cobalt sulphate in the medium; practically all RD cells are viable and can produce colonies at 2 days at concentrations of cobalt sulphate up to $2 \mathrm{mM}$. Cobalt sulphate becomes inhibitory to RD cells at $2.5-3 \mathrm{mM}$. At $3.5 \mathrm{mM}$ there is complete inhibition.

On the basis of these results it can be concluded that the RD colonies arising on a cobalt medium of between $\mathrm{I} \cdot 5$ and $2.5 \mathrm{mM}$ do so from $\mathrm{RD}$ cells present in the inoculum of otherwise normal, RG cells.

(iii) Analysis of the mixed colony type

Colonies arising on $\mathrm{I} \cdot 5 \mathrm{mM}$ cobalt sulphate which are comprised of a mixture of RG and RD cells are of particular interest. Since reversion of RD to $R G$ has never been observed (Ephrussi, I953 and Wilkie, unpublished) it must be assumed that this type of colony was initiated by an RC cell. A detailed study was carried out as follows: 390 cells of a glycerol-grown culture were plated on a $1 \cdot 25 \mathrm{mM}$ cobalt medium and the time taken to form colonies noted. Io per cent. of cells produced colonies after 2 days incubation, 22 per cent. after 4 days and 23 per cent. at 7 days. 45 per cent. failed to produce colonies 
after 8 days. (Presumably all of the inoculum cells were RG, for at most only I RD cell is expected in this sample.) The differential growth test was applied to these colonies with the following results:

A 2-day colony sampled at 2 days is mixed, consisting almost entirely of RD cells. Sampled at 4 days, the proportion of RC cells in these same colonies increases, and increases further at 7 days. Thus it can be concluded that RD cells proliferate early in the development of these colonies. Fig. 3 shows the detail of a mixed colony; the base of the colony consists of RD cells, whereas the central papilla is composed of $\mathbf{R C}$ cells.

Those colonies which arose at 4 days are mixed and show a disturbed colony resulting from RC cells overgrowing a mass of RD cells (fig. 2). The colonies which arose at 7 days, however, are uniform and are $\mathbf{R C}$.

In summary then, the viable $\mathrm{RC}$ cells of the original inoculum produced 2 types of colony, mixed and RC; no entirely RD colony was observed.

It was subsequently established that those $\mathrm{RC}$ cells which did grow at this concentration of cobalt sulphate $(1 \cdot 25 \mathrm{mM})$ were not stable cobalt-tolerant mutants.

It appears then that the ability of an RC cell to grow at this concentration of cobalt sulphate requires a process of physiological adaptation. That all cells of an RC strain do not adapt may be attributable to differences in their physiological state at the time of plating rather than to any genotypic difference. The exception to this, of course, is the RD cells present in the population.

However, the question as to whether the high frequency of RD cells in mixed colonies is the result of selection or induction is still unresolved. It was demonstrated that RD cells proliferate early in the "ontogeny" of the mixed colony. If they were the result of some induction event, it might be expected that all the progeny of the inoculum cell would be RD. However, the observations of Ephrussi (1953) from the archetype induction experiment using acriflavine are relevant in this regard. Ephrussi's results show that an RC cell growing in the presence of acriflavine produces almost exclusively $R D$ buds, but still retains the cytoplasmic factor and can produce $\mathrm{RC}$ buds when it is removed from acriflavine. Applied to the cobalt studies, it is conceivable that induction occurs during the first few divisions of the inoculum cell, but subsequent growth of the RD cells depletes the medium of cobalt, effectively lowering the extracellular concentration of the ion to below the critical concentration required for induction, thus allowing the RC inoculum cell to recover the ability to produce RC buds. However, the fact that RC cells isolated from $\mathrm{r} \cdot 25 \mathrm{mM}$ plates did not produce mixed colonies on re-exposure to $1 \cdot 25 \mathrm{mM}$ cobalt sulphate argues against this possibility. More direct evidence against induction was provided by single-cell studies which allowed the lineages of the inoculum cell to be followed. 
(iv) Single-cell studies on $1.25 \mathrm{mM}$ cobalt sulphate medium

An inoculum of strain $45 \mathrm{RC}$, pre-cultured as for the plating experiments, was suspended in distilled water and spread on a strip of glucose-YEP agar, $1 \cdot 25 \mathrm{mM}$ with respect to cobalt sulphate. The preparation was mounted in a dissection chamber and twenty single cells micromanipulated from the mass of cells were spaced out at $\mathrm{r} \mathrm{mm}$. intervals along the strip. After a period of 14 hours, 14 of these 20 cells produced clones, the number of cells per clone varying from 2 to 16 . The individual cells of three of these clones which contained 3,2 , and 9 cells respectively, were picked off the cobalt medium and transferred to a strip of cobalt-free glucose-YEP medium so that each cell could produce a colony. After 3 days only 2, 2, and 5 cells respectively actually gave rise to colonies. The differential growth test (glucose v. glycerol) showed that these colonies were RC, that is, none of the cells formed on cobalt medium was RD.

What is most impressive about these data is the lethality of cobalt sulphate to RC cells. Of the initial twenty single cells studied, 6 failed to produce buds in the alotted time and did not produce visible colonies after 8 days incubation. Also, among the progeny of the viable cells there is low viability. It can safely be assumed that the non-viable cells were not $\mathrm{RD}$, for in a parallel study with strain $45 \mathrm{SP}$ (a spontaneous RD strain) the results were strikingly different: all of the 19 single RD cells micro-manipulated produced clones of $12-16$ cells after 12 hours. The individual cells of 2 of these clones all produced colonies when transferred to cobalt-free medium, which verifies the assumption. This experiment also shows that mortality is not a result of the experimental technique.

The results of the experiments using $\mathrm{r} \cdot 25 \mathrm{mM}$ cobalt sulphate can be summarised as follows: the ability of an RC cell to grow at this concentration of cobalt sulphate requires physiological adaptation. However, only approximately $5^{\circ}$ per cent. of RC cells actually do adapt; the remainder are killed before they become adapted. The 7-day colony indicates that there is a lag period during which RC cells proliferate slowly. If during this period of growth-depression of the RC progeny, an RD bud arises spontaneously, since it requires no adaptation to this level of cobalt sulphate (Ioo per cent. of RD cells produce colonies at 2 days, $c f$. table 3 ), it is at a selective advantage until such time as the RC cells become adapted. Presumably this is what has occurred in the 2- and 4-day colonies, but in the 7-day colonies no $\mathrm{RD}$ cells arose while the $\mathrm{RC}$ cells were at a selective disadvantage.

\section{(v) Population study}

At $0.5 \mathrm{mM}$ cobalt sulphate RD cells have no apparent selective advantage ( $c f$. tables I and 3 ). A population study was performed to show whether there is induction at a concentration of cobalt sulphate which is not lethal to RC cells. (Acriflavine effects Ioo per cent. 
conversion of RC to RD in concentrations of the agent which do not result in cell death (Ephrussi, 1953).

For this experiment strain $45 \mathrm{RG}$ was pre-cultured as for the plating and single-cell experiments, that is, grown to stationary phase in non-fermentable medium, then inoculated into glucose-YEP broth, $0.5 \mathrm{mM}$ with respect to cobalt sulphate. These cells were allowed to grow to exponential phase (24 hours), the population harvested, washed with IomM sodium citrate to remove cobalt ion from the suspension (Hirota, 1956), and then plated on cobalt-free glucose-YEP medium. Of 577 colonies produced by the cobalt-grown cells, 8 were $\mathrm{RD}$, or $\mathrm{I} \cdot 4$ per cent., while the control grown in cobalt-free glucoseYEP prior to plating showed an RD frequency of $I \cdot 2$ per cent.

It can be concluded then that at a concentration of cobalt sulphate which can be tolerated by all RG cells, the proportion of RD to RG cells is the same as in the absence of cobalt sulphate.

This population study further supports the hypothesis that the relative increase in the proportion of $R G$ to $R D$ cells during growth on cobalt sulphate medium, at concentrations of $I \mathrm{mM}$ or greater ( $c f$. table $\mathrm{I}$ ) is a result of the selective disadvantage of $\mathrm{RG}$ cells on this medium.

(vi) Cobalt tolerance under anærobic conditions

Strain $45 \mathrm{RC}$ was prepared as for the previous experiments, and plated on medium containing cobalt sulphate in the concentrations $2,2.5$, and $3 \mathrm{mM}$. At these levels under ærobic conditions the only survivors were RD. These plates were incubated in an anærobic chamber (under nitrogen) for 7 days. At the end of this time the survival rate was found to be the same as under ærobic conditions; again the survivors were RD.

Also, anærobically pre-cultured cells of ${ }_{45} \mathrm{RC}$ failed to produce colonies on these concentrations of cobalt under ærobic conditions.

It is clear that the disadvantage of RC cells is not due to respiration. Further, in manometric studies performed by Dr D. Roodyn, (University College London), it was demonstrated that the oxygen uptake of glycerol-grown cells of strain $45 \mathrm{RC}$ was not impaired by the addition of $2.5 \mathrm{mM}$ cobalt sulphate, as compared to a control without cobalt sulphate. (Oxygen uptake was followed for a period of 5 hours).

Taken together, these results indicate that cobalt sulphate interferes with the growth of respiratory-competent cells rather than with the respiration process itself.

\section{(vii) Cobalt tolerance of a segregational petite}

For practical purposes it was assumed that all RD mutants arising spontaneously in strain $45 \mathrm{RC}$ were of the cytoplasmic, rho- type. This category of mutational change arises with a comparatively high frequency usually between $1^{-3}$ and $1^{-2}$. Nuclear mutations in the $p$-series of genes (see Wilkie, 1964) which are much less frequent, also 
give rise to respiratory deficiency (segregational type) which is biochemically similar to that of the rho-, vegetative type. Diploids obtained by crossing vegetative and segregational mutants are generally normal, RG, leading to the conclusion that the cytoplasmic genetic factor rho is present and intact in the segregational mutant and that $p$-alleles are recessive. By investigating a segregational petite it seemed possible to decide whether cobalt tolerance of RD cells was associated with the rho particle since it was already established that tolerance was not due to RD per se.

A gene-petite strain, $\mathrm{K}_{2}$ was isolated from strain I88RC by a combination of the visual test (Materials and Methods) and differential uptake of the dye Magdala Red (this technique is fully described in Horn and Wilkie, 1966). A single-gene difference from normal was verified by genetic tests.

TABLE 4

Cobalt tolerance of segregational and double mutants

\begin{tabular}{|c|c|c|c|}
\hline \multirow{2}{*}{$\begin{array}{c}\text { CoSO, } \\
(\mathrm{mM})\end{array}$} & \multicolumn{3}{|c|}{ Viability (per cent.) } \\
\cline { 2 - 4 } & $\mathrm{K}_{2}$ & $\mathrm{~K}_{2}$-SP & K2-AC \\
\hline & 19 & 100 & 100 \\
2 & 17 & 100 & 100 \\
$2 \cdot 5$ & 19 & 100 & 100 \\
3 & & & \\
\hline
\end{tabular}

When cells of strain $\mathrm{K}_{2}$ were plated out on YEP medium, 8o per cent. regularly produced cream-coloured colonies and 20 per cent. white ones. That the latter were "double mutants", that is carried the mutant gene $p$ and were $r h^{-}$, was demonstrated in crosses to a vegetative petite strain, $45 \mathrm{AC}$. In other words the frequency of the change to $r 0^{-}$was $2 \times 10^{-1}$ in $\mathrm{K}_{2}$.

Table 4 shows the results of plating cells of $\mathrm{K}_{2}, \mathrm{~K}_{2}-\mathrm{SP}$ (spontaneous double mutant) and $\mathrm{K}_{2}$-AC (acriflavine-induced double mutant of $\mathrm{K}_{2}$ ) on varying amounts of cobalt sulphate. As observed with strain ${ }_{45} \mathrm{RC}$, the survival rate on $2 \mathrm{mM}$ corresponds to the frequency of $r o^{-}$ cells in the population. The survivors of strain $\mathrm{K}_{2}$ when subcultured on YEP-glucose produced "white" colonies, a feature associated with $r h o^{-}$cells. It can be assumed that these survivors were the $r h o^{-}$ cells present in the $\mathrm{K}_{2}$ inoculum. These results show that it is respiratory-deficiency of the "cytoplasmic" type which confers a higher tolerance to cobalt sulphate.

In summary, rho- cells are more tolerant to cobalt sulphate in the medium compared to cells which contain the normal rho factor, whether or not the factor is functional in respiration. $R h^{+}$cells may become adapted to cobalt sulphate if exposed to gradually increasing concentrations of the salt. 
(viil) Uptake of cobalt ion by rho- cells

Presumably the toxicity of cobalt sulphate to both $r \mathrm{ho}^{+}$and $r h o^{-}$ cells is due to the cobalt ion being taken up by the cell and deranging metabolism. Cobalt is chelated by a variety of metabolites in vitro (amino acids, purines, and porphyrins), and may act in vivo by inactivating these molecules. (See Albert, 1960).

Whether the tolerance of rho- cells to concentrations of cobalt sulphate which are toxic to non-adapted $r h^{+}$cells is due to cobalt not getting into $r \mathrm{ro}^{-}$cells was tested in the following way:

Strain ${ }_{45} \mathrm{SP}$ (spontaneous $r \mathrm{r}^{-}$strain) was grown in glucose-YEP, $2 \mathrm{mM}$ with respect to cobalt sulphate. The cells were washed with IomM sodium citrate to remove the free cobalt ion. Qualitative determination of cobalt ion was made following Vogel (1954) using a I per cent. solution of I-nitroso-2-naphthol (Sigma, U.S.A.) in 50 per cent. acetic acid. This reagent complexes the cobaltous ion giving a reddish-brown precipitate (sensitivity: I part in 500,000).

A suspension of the washed cells were found to give a strong positive test for the ion. Microscopic examination of the treated cells showed that they were stained, but it was not possible to localise the site of the reaction. The control was an inoculum of the same strain grown in medium without added cobalt sulphate; these cells gave a negative test with the reagent.

These results show that $r h o^{-}$cells are not impermeable to the cobalt ion, and what is taken up by the cells is bound as washing with citrate does not remove it.

The cobalt ion was also found in adapted $r h o^{+}$cells of strain $45 \mathrm{RC}$.

Without further studies, which would probably involve the use of the radio-active isotope, cobalt- 58 , it is not possible to say whether the higher tolerance of $r h^{-}$cells is due to a slower uptake of the ion.

It appears cobalt is bound by the cells in a detoxified form. It would be of interest to know whether it is bound in the same form in $r h o^{+}$and $r o^{-}$cells; in other words are the detoxification mechanisms of the 2 cell types qualitatively or quantitatively different?

The possibility is not excluded however that cobalt initially forms a toxic complex with some substance present in $r h o^{+}$cells, the effect of which may be overcome by adaptation. It seems unlikely that cobalt reacts with the normal rho factor, on the existing evidence that the normal factor is dispensible and that agents which are selectively toxic to the factor result in the induction of the rho- mutant. However, the extraction and identification of a cobalt-complex in non-adapted $r \mathrm{~h}^{+}$ cells exposed to inhibitory concentrations of the ion may clarify this point.

\section{DISCUSSION}

It has been shown that non-adapted RD cells can grow at levels of cobalt sulphate which inhibit the growth of RC cells of the same strain. 
The inhibition of the RC cells appears to be due to the presence of the normal rho factor whether it is functional in respiration or not. RG cells can adapt to cobalt sulphate provided that the increase in the concentration of the salt is gradual and not above $1.25 \mathrm{mM}$.

The cobalt ion was found to be present in bound form in both adapted $\mathrm{RC}$ and $\mathrm{RD}$ cells suggesting that adaptation requires a detoxification process in which the complexed cobalt ion is diverted from interfering with vital synthetic processes. The main synthetic process to look at in this connection is probably DNA replication since the cobalt ion is known to bind tightly to DNA and alter its physical properties (Dove and Davidson, I962). Again cobalt can be chelated by amino acids so that protein synthesis may be deranged as a consequence of this aspect of cobalt activity.

Analysis of fractions of cells treated with radioactive cobalt may provide information on this point and indicate why a given concentration of cobalt ion in the medium is more inhibitory to RC than RD cells. A difference may be found in the amount of cobalt taken up by the different cell types or in a differential ability to detoxify the ion.

Although an explanation in biochemical terms of the phenotypic difference between $R C$ and $R D$ cells in their cobalt tolerance is not at hand, the phenomenon itself is of interest for it shows that the "cytoplasmic polymorphism" which characterises strains of $S$. cerevisie (Ephrussi, I953) can be of adaptive value to the species. Thus the proliferation of RD cells on concentrations of cobalt sulphate which inhibited but did not kill, RC cells, results in the lowering of the concentration of the ion in the medium as the RD cells accumulate it. This in turn facilitates the adaptation of RC cells. In the present case this effect was seen at a cobalt sulphate concentration of $I \cdot 25 \mathrm{mM}$. It would be of interest to see if this differential response of $\mathrm{RD}$ cells occurs with other toxic agents.

\section{SUMMARY}

I. Cells of the cytoplasmic respiratory mutant petite, show a resistance to cobalt sulphate about 3 times that of normal respiratory competent cells.

2. Normal cells growing anærobically in the presence of cobalt are no more resistant to the ion than under ærobic conditions.

3. Uptake of oxygen by normal cells is not impaired in the presence of inhibitory concentrations of cobalt sulphate. This observation together with the previous one leads to the conclusion that the respiratory system per se is not the site of action of the cobalt ion.

4. A respiratory mutant which was gene-determined but retained the cytoplasmic factor showed a cobalt sensitivity similar to that of the normal. The activity of the cobalt ion thus appears to be associated with the cytoplasmic determinant. 

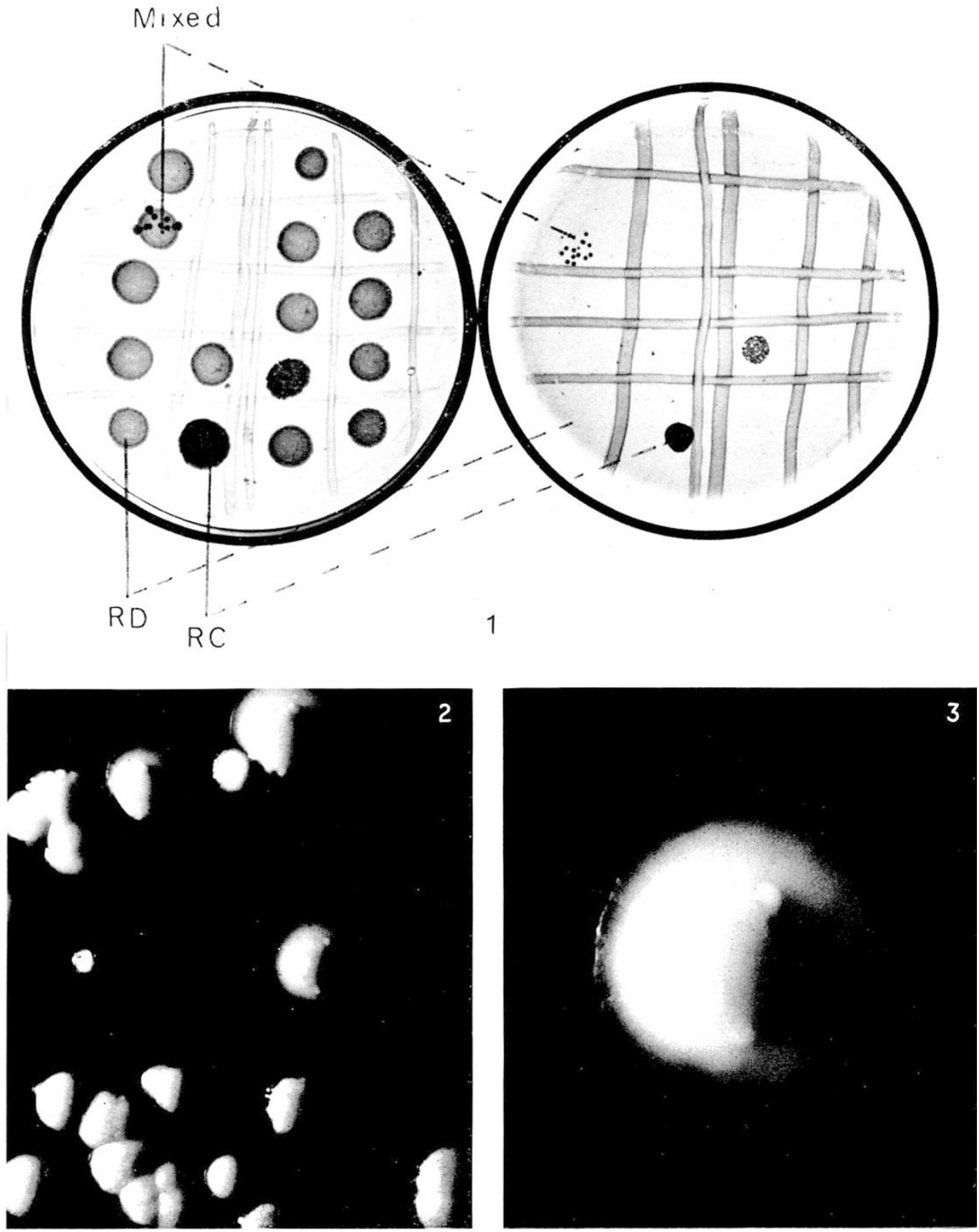

FIG. I.-Results of a typical differential growth test of cobalt-tolerant colonies. Corrcsponding squares on the replica plates received a duplicate spot inoculum from individual cell suspensions. Left: glucose-YEP medium; right: glycerol-YEP medium. RC: respiratory competent; RD: respiratory deficient.

Fig. 2.-Co!onies growing on a I.5 mM cobalt sulphate medium. "Mixed colonies (see text) show a central papilla of RC cells.

Fig. 3.-Ditail of a "mixed " colony. 


\section{REFERENCES}

ALbert, A. 196o. Selective Toxicity. Methuen, London.

CHEN, s., EPHRUSSI, B., AND HOTTINGUER, H. I950. Nature genetique des mutants a deficience respiratoire de la souche B-I I de la levure de boulangerie. Heredity, $4,337$.

DOVE, W. F., AND DAviDson, N. 1962. Cation effects on the denaturation of DNA. 7. Mol. Biol., 5, 467 .

EPHRUSSI, B. 1953. Nucleo-cytoplasmic relations in micro8organisms. Clarendon Press, Oxford.

EPHRUSSI, B., hOtTINGUER, H., AND CHIMENES, A. I949. Action de l'acriflavine sur les levures I. La mutation "petite colonie". Ann. Inst. Pasteur, 76, 351.

HIRotA, Y. 1956. Artificial elimination of the F-factor in Bact. coli K-12. Nature, $178,92$.

HIRota, Y. 1960. The effect of acridine dyes on mating type factors in $E$. coli. Proc. Natl. Acad. Sci., 46, 57.

HORN, P., AND WILKIE, D. Ig66. The use of Magdala Red for the detection of auxotrophic mutants of Saccharomyces cerevisia. F. Bacteriol., gI. (In the press).

LASKOWSKI, W. 1954. Induction par le chlorure de tetrazolium de la mutation "petite colony" chez la levure. Heredity, 8, 79.

LINDEGREN, C., NAGAI, S., AND NAGAI, H. 1958. Induction of respiratory deficiency in yeast by manganese, copper, cobalt and nickel. Nature, 182,446 .

NAGAI, s. 1963. Diagnostic color differentiation plates for hereditary respiratory deficiency in yeast. 7. Bacteriol., 86, 299.

OGUR, M., ST JOHN, R., AND NAGAI, S. 1957. Tetrazolium overlay technique for population studies of respiratory deficiency in yeast. Science, $125,928$.

RAUT, C., AND SIMPSON, L. W. 1955. Effect of X-rays and ultraviolet light of different wavelengths on the production of cytochrome deficient yeasts. Arch. Biochem. Biophys., 57, 218.

VOGEL, A. I. 1954. A textbook of macro- and semi-macro qualitative inorganic analysis. $4^{\text {th }}$ ed., Longmans, London.

WILKIE, D. 1963. The induction by monochromatic u.v. light of respiratory deficient mutants in ærobic and anærobic cultures of yeast. 7. Mol. Biol., 7, 527. WILkIE, D. 1964 . The cytoplasm in heredity. Methuen, London. 